\title{
Amplification of Portions of IGF-I and Insulin Genes and Characterisation of Variation in the Coding Sequence of Helmeted Guinea Fowl Numida meleagris
}

\author{
Iyetunde Ifeyori Adedibu ${ }^{1}$, Kolade Luke Ayorinde ${ }^{2}$, Ayo A. Toye ${ }^{2} \&$ Foluke Eunice Sola-Ojo ${ }^{2}$ \\ ${ }^{1}$ Department of Animal Science, Ahmadu Bello University, Zaria, Nigeria \\ ${ }^{2}$ Department of Animal Production, University of Ilorin, Ilorin, Nigeria \\ Correspondence: Iyetunde Ifeyori Adedibu, Department of Animal Science, Ahmadu Bello University, Zaria, \\ Nigeria. Tel: 234-803-600-1668, E-mail: iiipinyomi@yahoo.com
}

Received: May 13, 2013 Accepted: June 16, 2013 Online Published: August 15, 2013

doi:10.5539/jas.v5n9p204 URL: http://dx.doi.org/10.5539/jas.v5n9p204

\begin{abstract}
The study was undertaken to characterise and identify the insulin like growth factor-I (IGF-I) and insulin genes in five varieties (Ash, Black, Pearl Ash, Pearl Black and White) of local helmeted guinea fowl using DNA technology. Deoxyribonucleic acid (DNA) was purified from blood samples of the five varieties and Polymerase Chain Reaction (PCR) amplification of DNA done with primers designed to amplify the two genes; insulin-like growth factors I (IGF-I) and insulin (I). Purification of PCR product and dye terminator sequencing was also carried out using samples prepared and loaded into the Beckman Taq capillary sequencer. IGF-I gene profiles of Pearl Ash, White, Ash, Black varieties were similar (83 percent); and insulin gene profile of Pearl Ash, Ash, Black, Pearl Black varieties were 91 percent similar.
\end{abstract}

Keywords: genes, guinea fowl, insulin, IGF-I

\section{Introduction}

Most traits of economic interest in farm animals show continuous variation and the underlying genetic nature is complex (Huifang et al., 2010). According to Nahashon et al. (2005), there is paucity of information on guinea fowl genomics which if available and in sufficient quantity, can facilitate genetic improvement programs of the guinea fowl as well as other poultry species. One such improvement system which is hampered by lack of adequate background information is the candidate gene approach, which is a powerful method for understanding the direct genetic basis of quantitative differences between individuals (Rothchild \& Soller, 1997; Nagaraja et al., 2000). Single Nucleotide Polymorphism (SNP) in candidate growth genes can be evaluated for their effects on helmeted guinea fowl growth traits, and those that are significantly associated with growth traits can contribute to animal improvement through use in marker-assisted selection. While there are no known molecular markers for growth rate in the helmeted guinea fowl, studies (Amills et al., 2003; Yan et al., 2002; Feng et al., 1997, 1998) in closely related species including the domestic chicken have identified candidate genes for growth including Growth hormone (GH), Growth hormone receptor (GHR), Insulin-like Growth factor I (IGF-I), Insulin-like Growth factor I (IGF-II).

Insulin like growth factor-I (IGF-I) and insulin like growth factor-II (IGF-II) have been demonstrated as an indicator of growth rate in chicken by several authors (Jones \& Clemmons, 1995; Beccavin et al., 2001). Insulin like growth factor-I (IGF-I) has been well studied and showed consistent association with growth traits (Beccavin et al., 2001; Duclos, 2005) while insulin like growth factor-II (IGF-II) has also shown positive association with growth (Beccavin et al., 2001). The structural and functional similarities between insulin and the IGFs suggest they are the most closely related genes within the insulin super family and have diverged from a common ancestral gene (Ellsworth et al., 1994).

\subsection{Objectives of the Study}

To utilise Deoxyribonucleic acid (DNA) technology to identify the helmeted guinea fowl, IGF-I and insulin gene coding sequence and to determine their variation between five economically important helmeted Guinea Fowl varieties. 


\section{Materials and Method}

\subsection{Blood Collection}

Blood collection was as described by Ayorinde et al. (2001). About $2 \mathrm{ml}$ of fresh blood was collected by superficial venipuncture of a wing vein of each of twenty five (25) male helmeted guinea fowl of the 5 varieties identified. They include White (WV), Black (BLK), Ash (ASH), Pearl Black (PB) and Pearl Ash (PA) using a $2 \mathrm{ml}$ syringe (needle gauge, $23 \mathrm{G} \mathrm{x} \mathrm{11/4)} \mathrm{into} \mathrm{EDTA} \mathrm{sample} \mathrm{bottles.}$

\subsection{DNA Extraction and Purification}

High quality DNA purification from the whole blood was carried out using a commercial kit, ZR Genomic DNA -Tissue MidiPrep (Zymo Research Corp., USA). The protocol used is as described for whole blood, serum and plasma. The eluted DNA was stored at $-20^{\circ} \mathrm{C}$.

\subsection{Quantification of DNA Isolate}

A $1 \%$ agarose gel was used to quantify each DNA isolate by comparing its band intensity against a panel comprising graded levels of DNA resolved on the same gel. DNA bands were visualised by exposing the gel to Ultraviolet radiation in an Ultra violet (UV) ray box, GelDoc 2000 (BIO-RAD, USA) and documented using the ScionImage ${ }^{\circledR}$ Package.

\subsection{Selection of Gene Primers}

Gene primers were identified for the IGF-I and Insulin gene. As the the IGF-I and Insulin gene sequences were not known at the inception of the current study, Chicken gene primers were selected from a previous publication (Nie et al., 2005) for use in amplifying the helmeted guinea fowl ortholog. According to Nie et al. (2005), the sequences of the candidate genes of the somatotropic axis are from Genbank (http://www.ncbi.nlm.nih.org).The primers had been designed using the GENETOOL program (http://www.biologysoft.com). The primers used in this study were chosen from a total of 17 pairs of primers (forward and reverse) based on nucleotide sequence length. Primers were synthesised through a commercial service (BioNEER Corp., USA).

Information on the primers is given in the Table 1.

Table 1. Details of primers used for amplifying the IGF-I and Insulin genes

\begin{tabular}{|c|c|c|c|c|c|}
\hline Primer & Gene & $\begin{array}{c}\text { Sequence of oligonucleotide primers } \\
\text { (Forward primer 5'-3' } \\
\text { Reverse Primer 5'-3') }\end{array}$ & $\begin{array}{l}\text { Sequence } \\
\quad \text { ID }^{1}\end{array}$ & $\begin{array}{l}\text { Length } \\
\text { (bp) }\end{array}$ & $\begin{array}{l}\text { Annealing temperature for } \\
\text { PCR amplification }\left({ }^{\circ} \mathrm{C}\right)^{2}\end{array}$ \\
\hline 309 & IGF-I & AGCTGTTCGAATGATGGTGTTTT & AY253744 & 583 & 56.4 \\
\hline \multirow{3}{*}{1304} & \multirow{3}{*}{ Insulin } & GCCCCAGCATTCTCTTTCCTT & \multirow{3}{*}{ AY438372 } & \multirow{3}{*}{419} & 58.2 \\
\hline & & CTCCATGTGGCTTCCCTGTA / & & & 54.6 \\
\hline & & AATGCTTTGAAGGTGCGATAG & & & 53.5 \\
\hline
\end{tabular}

Source: Nie et al. (2005).

${ }^{1}$ Sequence accession numbers used for primer designing. ${ }^{2}$ Annealing temperature as specified by the manufacturer(BioNEER Corporation, USA).

The oligonucleotides were synthesized at a concentration of 100 picomole/ $\mu 1$. Each primer was diluted with distilled water (Water ultra Pure-Molecular Biology grade-free of detectable DNase/ RNase and protease by Quality Biological Inc.). A working dilution of $5 \mu \mathrm{l}$ was taken from each primer pair and put into a fresh microcentrifuge tube and made up to $100 \mu \mathrm{l}$ by adding distilled water (Water ultra Pure-Molecular Biology grade-free of detectable DNase/ RNase and protease by Quality Biological Inc) to be used for Polymerase Chain Reaction (PCR) amplification.

\subsection{Preparation of DNA Bulks}

The DNA isolated from each variety of guinea fowl was bulked by placing equal amounts of DNA isolated from each of five birds into a single microcentrifuge tube (BioNeer Corp.) such that five bulks were made; one each for White, Ash, Black, Pearl Black and Pearl Ash varieties. 


\subsection{Polymerase Chain Reaction (PCR) Amplification}

Fifty microliter $(50 \mu \mathrm{l})$ PCR reaction mixtures were prepared in each AccuPower ${ }^{\circledR}$ Hotstart PCR premix tube (BioNeer Corp., USA). Specifically, $1 \mu 1$ of each primer, $3 \mu 1$ DNA template, and $46 \mu l$ distilled water $\left(\mathrm{ddH}_{2} \mathrm{O}\right)$ were added. A PCR reaction was set up for each bulked template DNA representing each variety of helmeted guinea fowl. The reaction tube was put in a PERKIN ELMER GenAmp PCR system 2400 (USA) and the PCR condition was set at $94^{\circ} \mathrm{C}$ for 5 minutes for initial denaturing, followed by 35 cycles at $94^{\circ} \mathrm{C}$ for 30 seconds for denaturing, $52^{\circ} \mathrm{C}$ for 45 seconds for annealing, and $72^{\circ} \mathrm{C}$ for 1.30 minutes extension, and a final extension step at $72^{\circ} \mathrm{C}$ for 5 minutes. Samples were then stored at $4^{\circ} \mathrm{C}$ until required for purification.

\subsection{Purification of PCR Product}

Washing of the PCR product was done using AccuPrep ${ }^{\circledR}$ PCR Purification Kit by BioNEER Corporation (USA). This step removed the salts and soluble impurities in the DNA binding column tube. The loss of DNA in this step is negligible. The set up was dried by additional centrifugation at $13000 \mathrm{rpm}$ for $1 \mathrm{~min}$ to remove the residual ethanol and transfer the DNA binding filter column to a new $1.5 \mathrm{ml}$ micro-centrifuge tube. $30 \mu \mathrm{l}$ of Buffer 3 was added to the center of the DNA binding filter column and allowed to incubate for $10 \mathrm{~min}$ at $60^{\circ} \mathrm{C}$. The DNA was eluted by centrifugation at $13000 \mathrm{rpm}$ for $1 \mathrm{~min}$.

\subsection{Pre-Sequencing Conditioning}

Dye terminator sequencing was performed by use of GenomeLab ${ }^{\circledR}$ Dye terminator cycle sequencing (DTCS) with Quick start kit (BECKMAN COULTER, P/N 608120, USA). The sequencing reaction was prepared in a $2.0 \mathrm{ml}$ tube which was placed on ice $\left(40^{\circ} \mathrm{C}\right)$. All the reagents were kept on ice and added in this order; $9.5 \mu 1$ Distilled water $\left(\mathrm{dH}_{2} \mathrm{O}\right), 10 \mu \mathrm{l}$ DNA template, $2.0 \mu \mathrm{l}$ primers and $8.0 \mu \mathrm{l}$ DTCS Quick start master mix.

The tubes containing the sequencing reaction mixture were placed in a thermocycler and the following thermal cycling profile was applied: $96^{\circ} \mathrm{C}$ for 20 seconds, then $50^{\circ} \mathrm{C}$ for 20 seconds and $60^{\circ} \mathrm{C}$ for 4 minutes x 30 cycles

\subsection{Ethanol Precipitation}

A labelled sterile $0.5 \mathrm{ml}$ tube was prepared for each sample. Five microlitres $(5 \mu 1)$ of the prepared stock solution/ glycogen mixture (i.e. mixture of $2 \mu \mathrm{l}$ of 3 M Sodium acetate, $2 \mu 1$ of $100 \mathrm{mM} \mathrm{Na} 2$-EDTA and $1 \mu \mathrm{lof} 20 \mathrm{mg} / \mathrm{ml}$ of glycogen provided in the kit) was added to each labelled tube and then the sequencing reaction was transferred to each of the appropriately labelled tube and mixed thoroughly. Sixty microlitres $(60 \mu \mathrm{l})$ of cold $95 \%$ ethanol taken straight from $-20^{\circ} \mathrm{C}$ freezer was added and mixed thoroughly, centrifuged at $14,000 \mathrm{rpm}$ at $4^{\circ} \mathrm{C}$ for 15 minutes. The supernatant was carefully removed with micropipettes to reveal a visible pellet in each of the tubes. The pellets were rewashed with $200 \mu 1$ of $70 \%$ ethanol taken straight from $-20^{\circ} \mathrm{C}$ freezer, centrifuged at $14000 \mathrm{rpm}$ at $4^{\circ} \mathrm{C}$ for 2 minutes. Each of the tubes was left open to enable the pellet to dry. The samples were re-suspended in $40 \mu 1$ of the sample loading solution that was provided in the kit.

\subsection{Sequencing}

The re-suspended samples were transferred into the appropriate wells of the sample plate BECKMAN COULTER, USA (PN 609801) and documented manually for easy identification. Each of the re-suspended samples that had been transferred to the wells was overlaid with a drop of mineral oil provided in the kit.

The sample plate was loaded into the sequencing machine, BECKMAN COULTER CEQTM 2000XL DNA Analysis System (USA) and programmed.

\subsection{Sequence Alignment}

The sequences obtained were aligned with the software, CLC Bio Workbench Version 6.7.1 with criteria of maximising similarity and minimising the number of inferred evolution events (Hackett et al., 2008). For each gene region, Neighbour-Joining algorithm was applied to compare evolutionary distance (Hackett et al., 2008).

\section{Results and Discussion}

Figure 1 show that there are conserved regions in the multiple sequence alignment of IGF-I gene of four varieties of helmeted guinea fowl. There were however indels in the 0-19 region of Pearl Ash, Ash and Black varieties. Indels occurred more frequently in the IGF-I gene of Black variety in the following regions, 109-111, 126, 127, 156-164, 179, 180, 274-281, 297-298, 538, 539. These indels ( gaps) may have been introduced in the time since these varieties of helmeted guinea fowl diverged from one another representing a major mutational process of the IGF-I gene evolution (Taylor et al., 2004). The indels observed in these study occurred in regions (position 536-540 in Pearl Ash, Ash, Black and White varieties) where amino acid sequences were not well conserved thereby making exact placement of the event difficult (Taylor et al., 2004). 


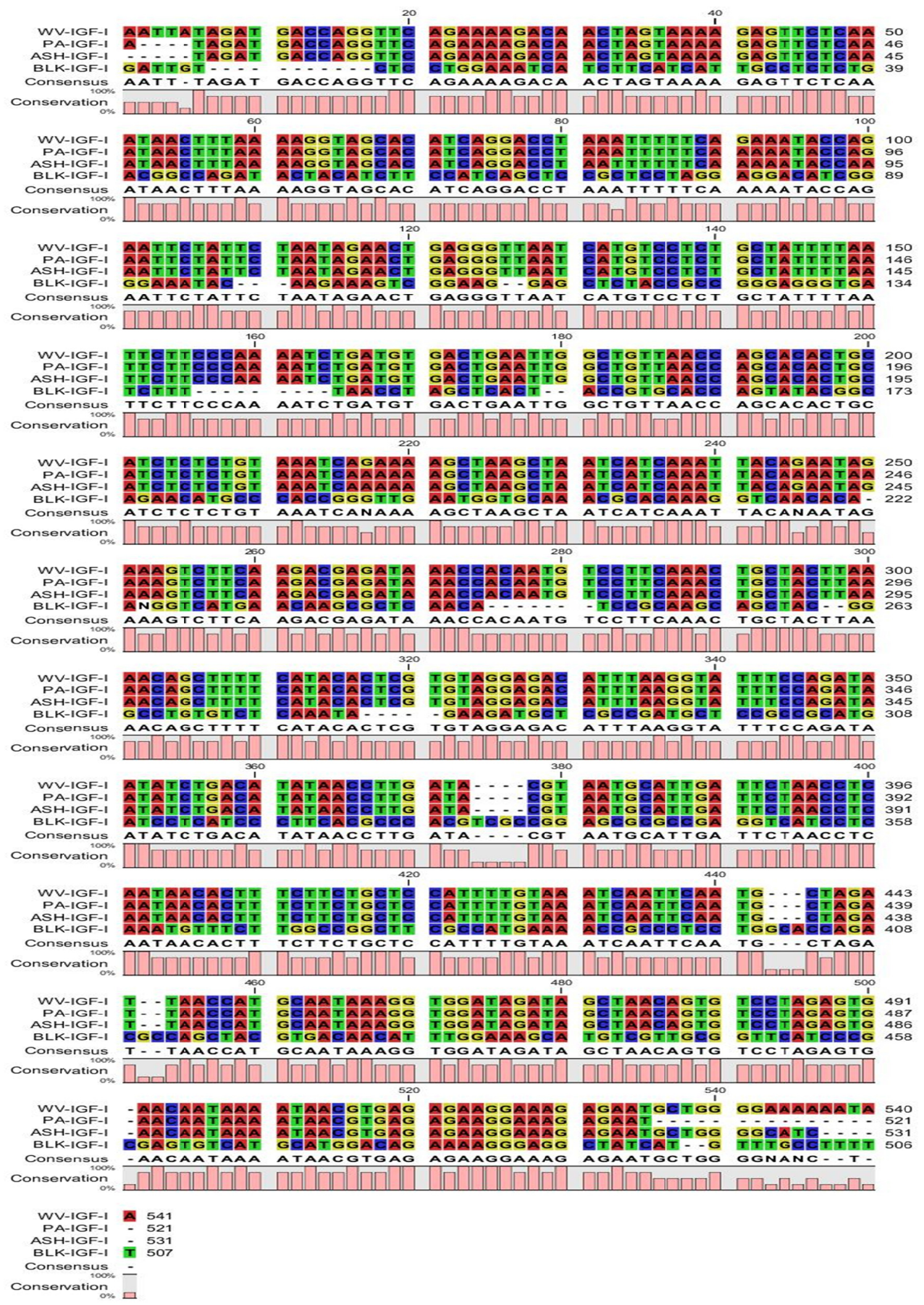

Figure 1. Multiple sequence alignment of IGF-I gene of White, Pearl Ash, Ash and Black varieties of helmeted guinea fowl

In Figure 2, the IGF-I profile of Pearl Ash, White, Ash and Black varieties were related (83 percent). IGF-I gene profile of Pearl Ash, White, Ash varieties were more closely related than Black variety which could be attributed to 
the magnitude of indels reported in Figure 1 of the Black variety. IGF-I gene is an important candidate gene that affects the chicken muscle cell development and reproduction, and is associated with bodyweight, breast weight, and breast yield (Amills et al., 2003). Myofiber numbers and myofiber densities have also been reported (Scheuermann et al., 2003, 2004) to be related to body weight, breast weight, and breast yield, thus the IGF-I gene could affect the chicken muscle fiber growth (Lei et al., 2007). The sequence of helmeted guinea fowl IGF-I gene derived from this study extend knowledge of the genome and form foundational information upon which genetists may search for assertions between Single nucleotide polymorphism (SNPs) and production (improved bodyweight, breast weight, and breast yield) in helmeted guinea fowl and or such associations as a basis for mass assisted selection (MAS).

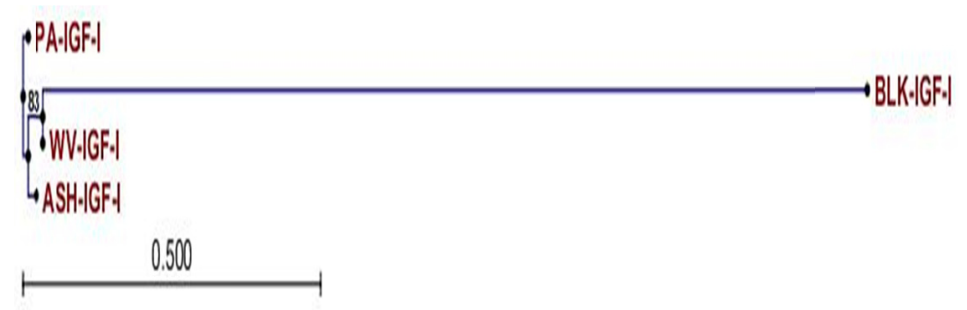

Figure 2. Phylogram of different varieties of Helmeted guinea fowl and IGF-I

Key: PA(Pearl Ash), WV(White), ASH(Ash), BLK(Black).

The insulin gene of Black, Ash, Pearl Ash varieties had many conserved regions between them (Figure 3). Pearl Black variety however had gaps from 1-161 region of the aligned sequence. There was no conserved nucleotide in position 1 of the aligned sequence (Figure 3) substantiating the report of Taylor et al. (2004) that indels occur frequently in regions where amino acid sequences are not well conserved thus making an exact placement of the event (whether insertion or deletion) difficult to explain. 


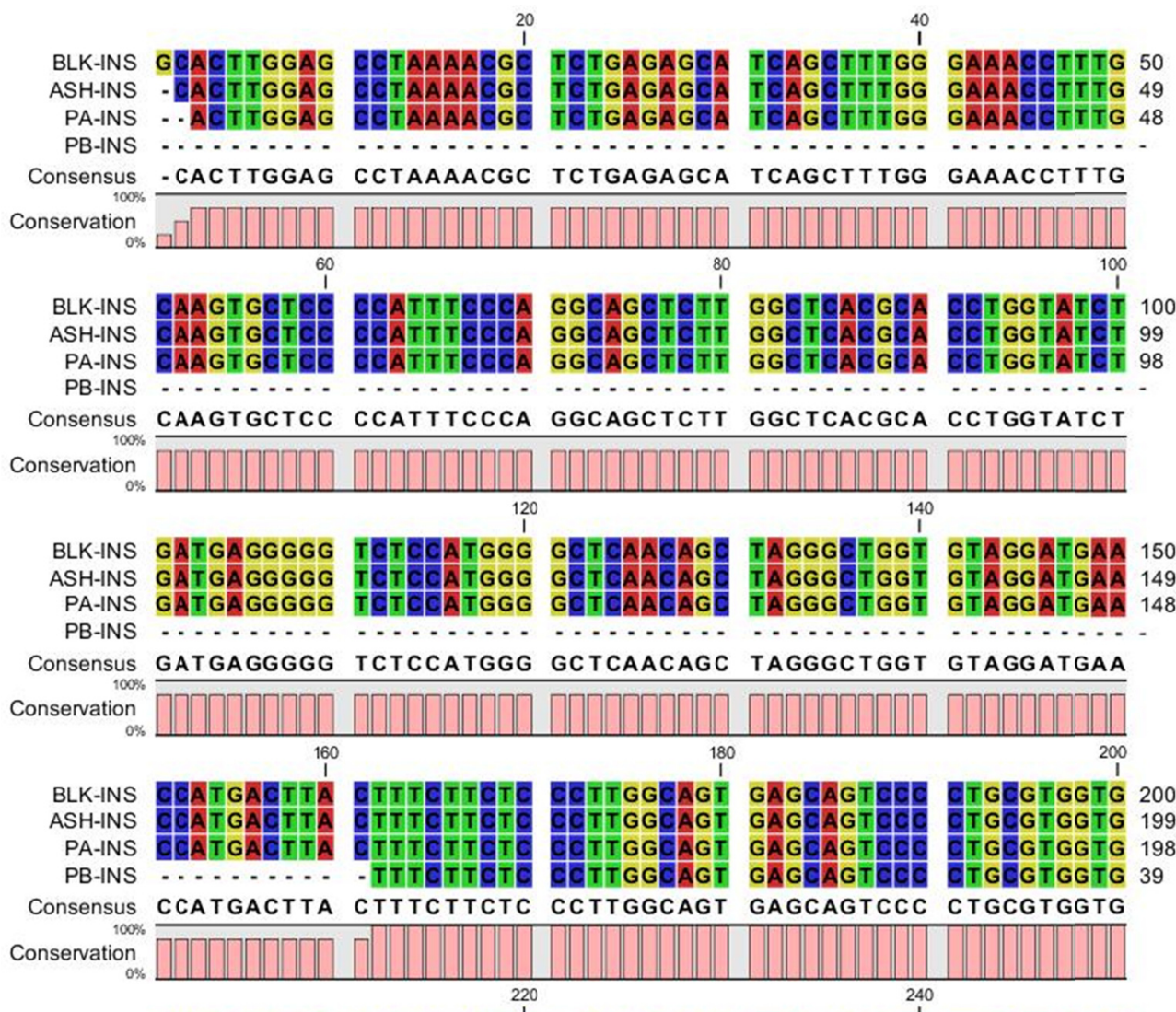

BLK-INS AGGTAGGAGT GCTGCCCTTC CAGCAGGAGG AATACGAGAA GGTCAAGAGA 250 ASH-INS AGGTAGGAGT GCTGCCCTTC CAGCAGGAGG AATACGAGAA GGTCAAGAGA 249

PA-INS AGGTAGGAGT GCTGCCCTTC CAGCAGGAGG AATACGAGAA GGTCAAGAGA 248

PB-INS AGGTAGGAGT GCTGCCITTC CAGCAGGAGG AATACGAGAA GGTCAAGAGA 89

Consensus AGgTAGgAGT GCTGCCCTTC CAGCAGgAGG AATACGAGAA GgTCAAGAGA Conservation ${ }_{0 \%}^{100 \%}$

BLK-INS GGGATTGTTG AGCAATGCTG CCATAACACG TGCTCTCTCT ACCAACTGGA 300

ASH-INS GGGATTGTTG AGCAATGCTG CCATAACACG TGCTCTCTCT ACCAACTGGA 299

PA-INS GGGATTGTTG AGCAATGCTG CCATAACACG TGCTCTCTCT ACCAACTGGA 298

PB-INS GGGATTGTTG AGCAATGCTG CCATAACACG TGCTCTCTCT ACCAACTGGA 139

Consensus GGGATTGTTG AGCAATGCTG CCATAACACG TGCTCTCTCT ACCAACTGGA

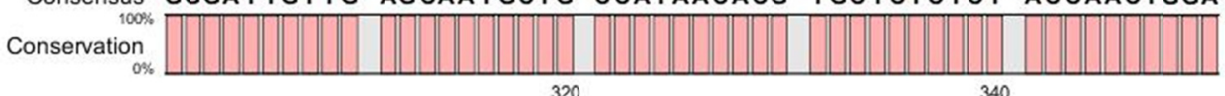

320

BLK-INS GAACTACTGC AACTAGCCAA GAGGCTGGCG GTGGGCACAG ACATGCACTT 350

ASH-INS GAACTACTGC AACTAGCCAA GAGGCTGGCG GTGGGCACAG ACATGCACTT 349

PA-INS GAACTACTGC AACTAGCCAA GAGGCTGGCG GTGGGCACAG ACATGCACTT 348

PB-INS GAACTACTGC AACTAGCCAA GAGGCTGGCG GTGGGCACAG ACATGCACTT 189

Consensus GAACTACTGC AACTAGCCAA GAGGCTGGCG GTGGGCACAG ACATGCACTT Conservation
$0 \%$

BLK-INS ACTCTATCGC ACCTTCAAAG CATTA 375

ASH-INS ACTCTATCGC ACCTTCAAAG CATTA 374

PA-INS ACTCTATCGC ACСTT........

PB-INS ACTCTATCGC ACCTtCAAA- .... 208

Consensus ACTCTATCGC ACCTTCAAAG CATTA

Conservation

Figure 3. Multiple sequence alignment of Insulin gene of Pearl Black, Pearl Ash, Ash and Black varieties of helmeted guinea fowl 
The Insulin profile of all the four varieties of helmeted guinea fowl were closely related (Figure 3). However, Pearl Ash, Ash and Black varieties' Insulin profile were more closely related than Pearl Black's. This could be due the gaps reported in Figure 3.

The genes of the somatotropic axis not only affected chicken growth and body compositions but also were associated with fatness and muscle fiber traits (Lei et al., 2007). Insulin gene has linked with the muscle fiber density (Lei et al., 2007). the significance of helmeted guinea fowl Insulin genes in this study is thus foundational information upon which genetists may search for associations between SNPs and production traits such as lean meat in helmeted guinea fowl and such associations could form a basis for marker assisted selection (MAS).
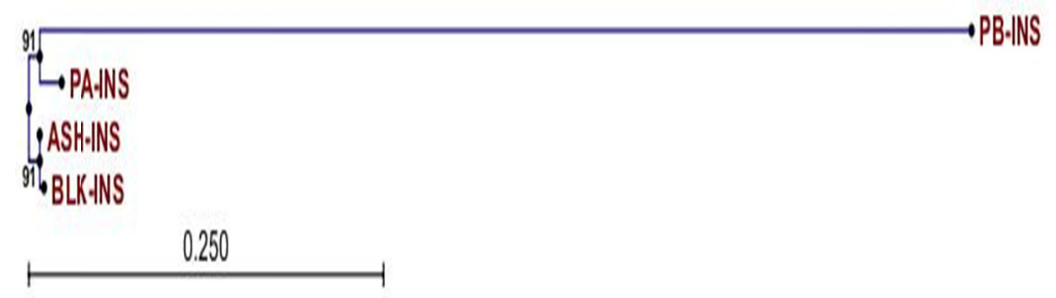

Figure 4. Phylogram of different varieties of helmeted guinea fowl and Insulin

Key: PA (Pearl Ash), ASH (Ash), BLK (Black)PB (Pearl Black), INS (Insulin).

\section{Conclusion}

There are similarities in the IGF-I gene profiles of Pearl Ash, White, Ash, Black varieties; and insulin gene profile of Pearl Ash, Ash, Black, Pearl Black varieties. The success of amplifying genes of IGF-I and Insulin by primers derived from chicken on helmeted guinea fowl highlights the value of use of comparative genomic approach in discovering information-poor species by use of information from information-rich species, and the success of this approach is consistent with shared evolutionary origin of the birds.

\section{References}

Amills, M., Jimenez, N., Villalba, D., Tor, M., Molina, E., Cubilo, D., ... Estany, J. (2003). Identification of three single nucleotide polymorphisms in the chicken insulin-like growth factor 1 and 2 genes and their associations with growth and feeding traits. Poultry Science, 82, 1485-1493.

Ayorinde, K. L., Song, Y., Durmmond, P., \& Smith, E. J. (2001). Molecular genetic analysis of diversity in village chickens in Nigeria. Nigerian Journal of Animal Production, 28(2), 128-134.

Beccavin, C., Chevalier, B., Cogburn, L. A., Simon, J., \& Duclos, M. J. (2001). Insulin-like growth factors and body growth in chickens divergently selected for high or low growth rate. Journal of Endocrinology, 165, 297-306. http://dx.doi.org/10.1677/joe.0.1680297

Duclos, M. J. (2005). Insulin-like growth factor-I (IGF-I) mRNA levels and chicken muscle growth. Journal of Physiology and Pharmacology, 56(suppl.3), 25-35.

Ellsworth, D. L., Hewett-Emmett, D., \& Li, W. (1994). Evolution of Base Composition in the Insulin and Insulin- Like Growth Factor Genes. Molecular Biology and Evolution, 11(6), 875-885.

Feng, X. P., Kuhnlein, U., Aggrey, S. E., Gavora, J. S., \& Zadworny, D. (1997). Trait association of genetic markers in the growth hormone and growth hormone receptor gene in a white Leghorn strain. Poultry Science, 76, 1770-1775. http://dx.doi.org/10.1093/jhered/89.4.355

Feng, X. P., Kuhnlein, U., Faithfull, R. W., Aggrey, S. E., Yao, J., \& Zadworny, D. (1998). A genetic marker in the growth hormone receptor gene associated with body weight in chickens. Journal of Heredity, 89, 355-359.

Hackett, S. J., Kimball, R. T., Reddy, S., Bowie, R. C. K., Braun, E. L., Braun, M. J., ... Yuri, T. (2008). A Phylogenomic Study of Birds Reveals Their Evolutionary History. Science, 320, 1763.

Jones, J. I., \& Clemmons, D. R. (1995). Insulin-like growth factors and their binding proteins: Biological action. Endocrine Reviews, 16, 3-34. 
Lei, M., Luo, C., Peng, X., Fang, M., Nie, Q., Zhang, D., Yang, G., \& Zhang, X. (2007). Polymorphism of Growth-Correlated Genes Associated with Fatness and Muscle Fiber Traits in Chickens. Poultry Science, $86,835-842$.

Nagaraja, S. C., Aggrey, S. E., Yao, J., Zadworny, D., Fairfull, R. W., \& Kuhnlein, U. (2000). Trait association of a genetic marker near the IGF-I gene in egg-laying chicken. Journal of Heredity, 91, 150-156. http://dx.doi.org/10.1093/jhered/91.2.150

Nahashon S. N., Payne, L., Amenyenu, A., Adesope, N., \& Wright, D. (2005). Chicken specific primers reveal endogenous retroviral elements in guinea fowl. Poultry Science, 84(suppl.1), 130.

Nie, Q., Lei, M., Ouyang, J., Zeng, H., Yang, G., \& Zhang, X. (2005). Identification and characterization of single nucleotide polymorphisms in 12 chicken growth-correlated genes by denaturing high performance liquid chromatograpy. Genetics Selection Evolution, 37, 339-360. http://dx.doi.org/10.1186/1297-9686-37-4-339

Rothchild, M. F., \& Soller, M. (1997). Candidate gene analysis to detect traits of economic importance in domestic livestock. Probe, 13-22.

Scheuermann, G. N., Bilgili, S. F., Hess, J. B., \& Mulvaney, D. R. (2003). Breast muscle development in commercial broiler chickens. Poultry Science, 82, 1648-1658.

Scheuermann, G. N., Bilgili, S. F., Tuzun, S., \& Mulvaney, D. R. (2004). Comparison of chicken genotypes: Myofiber number in pectoralis muscle and myostatin ontogeny. Poultry Science, 83, 1404-1412.

Taylor, M. S., Ponting, C. P., \& Copley, R. R. (2004). Occurrence and Consequences of Coding Sequence Insertions and Deletions in Mammalian Genomes. Genome Research, 14(4), 555-566. http://dx.doi.org/10.1101/gr.1977804

Yan, B., Li, N., Deng, X., Hu, X., Liu, Z., Zhao, X., Lian, Z., \& Wu, C. (2002). Single nucleotide polymorphism analysis in chicken insulin-like growth factor-II gene and its associations with growth and carcass traits. Acta Genetica Sinica, 29, 30-33.

\section{Copyrights}

Copyright for this article is retained by the author(s), with first publication rights granted to the journal.

This is an open-access article distributed under the terms and conditions of the Creative Commons Attribution license (http://creativecommons.org/licenses/by/3.0/). 